uets of DCP action. The two enzymes were not separated by ion-exchange column chromatography on DEAE-cellulose, by gel filtration, or by polyacrylamide gel electrophoresis. Even the activity-pH curves were found to be rery similar. Separation of the two enzwes was exentually achieved by chromatography through hydroxyapatite columns. The complementary action of the two enzymes on the carboxyl ends of polypeptide chains represents an alternative mechanism for carboxypeptidase action by which a polypeptide chain is successively degraded. from the earboxyl end to amino acids. An interesting regulatory mechanism is indicated by the finding that the dipeptides formed by DCP act as competitive inhibitors of this enzyme and in turn serve as substrates for dipeptidase, the activity of which depends on Mn ions.

\title{
Acknowledgment
}

The financial support granted by the Helena Rubinstein Foundation Inc. is gratefully acknowledged.

\section{[51] Exocellular DD-Carboxypeptidases-Transpeptidases from Streptomyces}

\author{
By Jeax-Marie Frére, Mélixa Leyh-Botille, Jeax-Marie Ghuxsex, \\ Maxtel Nieto, and Harold R. Perkixs
}

\section{Strains and Culture}

Strains. Strains R39 and R61 are soil isolates, ${ }^{1,2}$ Their designations are arbitrary. In strain R39, the cross-link between the peptide units of the wall peptidoglycan extends from the C-terminal in-alanine of one unit to the amino group at the D-center of meso-diaminopimelic acid of another unit ${ }^{3}$ (peptidoglycan of chemotype I). ${ }^{4}$ The interpeptide bond is in $\alpha$-position to a free carboxyl group. In strain R6], the cross-link extends from a C-terminal $\mathrm{D}$-alanine of a peptide unit to a glyeine residue attached to the e-amino group of LL-diaminopimelic aride another peptide unit ${ }^{5}$ (peptidoglycan of chemotype II). ${ }^{4}$ The exocellular DD-

${ }^{1}$ M. Welsch. Rev. Belge Pathol. Med. Exp. 18, Suppl. 2.1 (1947).

${ }^{2}$ M. Welsch and A. Rutien-Pinckiters. Bull. Soc. R. Sci. Liegt. 3-4, 374 (1963)

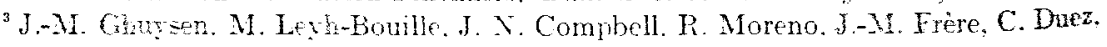

M. Nieto. and H. P. Perhine, Binchemistry 12, 1213 (1973).

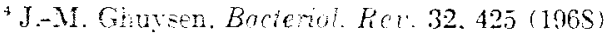

"M. Irm-Bonille. P. Bonaly. J-M. Ghuren. R. Tinelli, and D. J. Tipner. Bioricmitry 9, $2944(1940)$. 
arboxypentidases-transpeptidases produced by both strains 11 catalyze indrolyeis and transier reactions according to the gcneral equations $\mathrm{R}-\mathrm{D}-\mathrm{Ala}-\mathrm{D}-\mathrm{Ala}+\mathrm{H}, \mathrm{O} \rightarrow \mathrm{D}-\mathrm{Ala}+\mathrm{R}-\mathrm{D}-\mathrm{Ala}$ (DD-carboxyeptidase actirity) and $\mathrm{R}-\mathrm{D}-\mathrm{Ala}-\mathrm{D}-\mathrm{Ala}+\mathrm{NH}-\mathrm{R}^{\prime} \rightarrow \mathrm{D}-\mathrm{Ala}+\mathrm{R}-\mathrm{D}-\mathrm{Ala}-\mathrm{R}^{\prime}$ (transpeptidase activity) and (2) react with $\beta$-lactam antibiotics (i.e., penicillins and cephalosporins! to form equimolar and inactive antibiotic-enzyme complexes of various half-lives. Both R39 strain and, to a much lesser extent, strain R61 also produce an exocelular $\beta$-lactamase (penicillinase, EC 3.5.2.6) which hydrolyzes penicillin to penicilloic acid.

Culture Media. Peptone oxoid medium contains $1 \%$ peptone oxoid, $0.1 \% \mathrm{~K}_{2} \mathrm{HPO}_{4}, 0.1 \% \quad \mathrm{MgSO}_{4} \cdot 7 \mathrm{H}_{2} \mathrm{O}, 0.2 \% \mathrm{NaNO}_{3}$, and $0.005 \% \mathrm{KCl}$ in water.

Glycerol-casein medium contains per liter of final volume: $20 \mathrm{~g}$ of glycerol, $40 \mathrm{ml}$ of $10 \%$ casein solution $(\mathrm{w} / \mathrm{v})$, and $50 \mathrm{ml}$ of salt suspension. The salt suspension contains per liter: $5 \mathrm{~g}$ of $\mathrm{NaCl}, 1 \mathrm{~g}$ of $\mathrm{CaCO}_{3}$, $1 \mathrm{~g}$ of $\mathrm{MgSO}_{4} \cdot 7 \mathrm{H}_{2} \mathrm{O}, 10 \mathrm{~g}$ of $\mathrm{K}_{2} \mathrm{HPO}_{4}$, and $1 \mathrm{~g}$ of $\mathrm{FeSO}_{4} \cdot 7 \mathrm{H}_{2} \mathrm{O}$. The casein is previously dissolved at $70^{\circ}$ with the help of $\mathrm{KOH}(0.04 \mathrm{~g}$ per gram casein). The solution is then cooled and neutralized.

Agar-APG medium contains per liter of final volume: agar $20 \mathrm{~g}$; asnaragine, $0.5 \mathrm{~g}$; peptone oxoid, $0.5 \mathrm{~g}$; glucose, $10 \mathrm{~g}$; and $\mathrm{K} . \mathrm{HPO}_{4}, 0.5 \mathrm{~g}$.

Agar-KC medium contains per liter of final volume: agar, $20 \mathrm{~g}$; partially hydrolyzed keratin from white hens' feathers, $2.5 \mathrm{~g}$; partially hydrolyzed casein, $2.5 \mathrm{~g} ; \mathrm{NaCl}, 0.5 \mathrm{~g} ; \mathrm{CaCO}_{3}, 0.1 \mathrm{~g} ; \mathrm{MgSO} \cdot 7 \mathrm{H}, 0,0.1$ $\mathrm{g} ; \mathrm{K}_{2} \mathrm{HPO}_{4}, 1 \mathrm{~g}$; and $\mathrm{FeSO}_{4} \cdot 7 \mathrm{H}_{2} \mathrm{O}, 0.1 \mathrm{~g}$. The final $\mathrm{pH}$ is 7.5 . Hydrolyzed keratin and casein are prepared as follows: $100 \mathrm{~g}$ of dried. white hens' feathers are treated for $1 \mathrm{hr}$ at $100^{\circ}$ with 1 liter of $0.125 \times \mathrm{KOH}$. After centrifugation, casein (100 g) is added to the supernatant fraction and dissolved by heating at $70^{\circ}$. The $\mathrm{pH}$ of the mixture (final volume, 1 liter) is adjusted to $7.5-8.0 ; 25 \mathrm{ml}$ contain $2.5 \mathrm{~g}$ of both partially hydrolyzed keratin and casein.

Maintenance of Strains. Strain R39 is grown at $28^{\circ}$ on slants of agar-FC, and strain of R61 on slants of agar-APG. Abundant sporulation occurs after $4-5$ days. The strains are then maintained at 4 .

\section{Assay Methods for DD-Carboxypeptidase Activity}

\section{Standard Reaction}

$$
A c-L-L y-D-A l a-1-A l a+H_{2} O \rightarrow D-A l a+A c a-L y s-n-A l a
$$

Cnit. One unit of DD-carboxypeptidase catalyzes the hydrolysis of 1

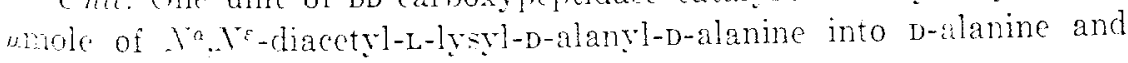


$X^{\alpha} . X^{*}$-diacetyl-L-lysyl-D-aianine per minute at $3 \%$ under conditions of enzyme saturation by the substrate.

Substrate. Trineptide Ac-L-LY - -D-Ala-D-Ala is prepared as described by Nieto and Perkins. ${ }^{6}$

Standard Incubation Conditions. Streptomyces R39 enzyme: Ac Lys-D-Ala-D-Ala $(0.25 \mu$ mole $)$. is incubated with the enzyme at $37^{\circ}$ in $30 \mu$ lfinal volume) of $0.03 \mathrm{M}$ Tris- $\mathrm{HCl}$ buffer, $\mathrm{pH} 7.5$, supplemented with $3 \mathrm{~m} . / \mathrm{MgCl}$. Final substrate concentration is $8 \mathrm{~m} .1$, i.e., $10 \times$ the $K_{\mathrm{m}}$ value $(0.8 \mathrm{~m} . \boldsymbol{H})$.

Streptomyces R61 enzyme: Ac-L-Lys-D-Ala-D-Ala $(0.36 \mu$ mole $)$ is incubated with the enzyme at $37^{\circ}$ in $30 \mu \mathrm{l}$ of either $5-10 \mathrm{~m} . M$ sodium phosphate buffer $\mathrm{pH} 7.5$ or $10 \mathrm{~m} . /$ Tris-HCl buffer $\mathrm{pH}$ 7.5. Final substrate concentration is $12 \mathrm{~m} M$. i.e., equivalent to the $K_{\mathrm{n}}$ value. For this enzyme, assays are thus carried out at half the maximum velocity.

The $\mathrm{D}$-Ala released during the reaction is estimated by using one of the following techniques.

\section{Chemical Estimation of Free Alanine}

The following is a modification of the technique of Ghuysen et al:

$F D \wedge B$ Reagent. Fluorodinitrobenzene, $130 \mu \mathrm{l}$ in $10 \mathrm{ml}$ of $100 \%$ ethanol.

Procedure. Samples containing 10-50 nmoles of alanine are mixed with $10 \% \mathrm{~K}_{2} \mathrm{~B}_{4} \mathrm{O}_{i}$ and water to give a total volume of $100 \mu \mathrm{l}$ of $1 \%$ $\mathrm{K}_{3} \mathrm{~B}_{4} \mathrm{O}_{7}$. FDNB reagent $(10 \mu \mathrm{l})$ is added. The solutions are mixed and incubated at $60^{\circ}$ for $30 \mathrm{~min}$. After acidification with $50 \mu \mathrm{l}$ of $12 \mathrm{~N} \mathrm{HCl}$, the DNP-alanine is extracted three times with $200 \mu$ l of ether. The ether extracts are evaporated in a stream of hot air and dried in vacuo. The residues are dissolved in methanol and chromatographed at room temperature on thin-layer plates of silica gel $G$ in chloroform:methsnol : acetic acid $(220: 25: 5 . \mathrm{v} / \mathrm{v} / \mathrm{v})$. DNP-alanine moves faster than DNPTris. After drying. the DNP-alanine spots are transferred to 1 -ml tubes and eluted by vigorous mixing with $500 \mu \mathrm{l}$ of water:ethanol:25\% (sperific gravity 0.911 ammonia $(100: 100: 0.54, \mathrm{v} / \mathrm{r} / \mathrm{r}$. After centrifugation, the optical density of the supernatant fractions is measured at $360 \mathrm{~nm}$. The molar extinetion coefficient for DNP-alanine is about 15.000.

\section{Enzymic Estimation of 4-Alanine}

The following modification of the technique of Chuysen et al." permits many simultaneous tests to be carried out in a very short time.

: M. Xino and H. P. Perkins. Biochem. J. 123, 789 (1971).

'J.-M. Gumsen, D. J. Tipper. and J. L. Strominger this series Vol. 8. 1. 685. 
licagents

o-Dianisidine (Merck, analytical grade): $10 \mathrm{mg} / \mathrm{ml}$ in methanol (freshly prepared)

K prophosphate buffer. $0.1 \mathrm{M}, \mathrm{pH} 8.3$

FAD (monosodium; Boehringer), $0.3 \mathrm{mg} / \mathrm{ml}$ in pyrophosphate buffer Peroxidase (Boehringer, Reinheitsgrad 1, für analytische Zwecke; suspension $10 \mathrm{mg} / \mathrm{ml}$ ) to be diluted to $10 \mu \mathrm{g} / \mathrm{ml}$ in $\mathrm{H}_{2} \mathrm{O}$

D-Amino acid oxidase (Boehringer, für inalytische Zweke; Kristallsuspension, $5 \mathrm{mg} / \mathrm{ml}$ )

Enzymes and coenzyme mixture (freshly prepared): pyrophosphate buffer:FAD solution:diluted peroxidase solution:D-amino acid oxidase suspension $(20: 10: 5: 1, \mathrm{v} / \mathrm{v} / \mathrm{v} / \mathrm{v})$

Procedure. Samples $(30 \mu \mathrm{l})$ containing $5-40$ nomoles of $\mathrm{D}$-alanine (from the hydrolyzed substrate) are mixed with $5 \mu$ l of 0 -dianisidine solution and $70 \mu \mathrm{l}$ of the enzymes-coenzyme mixture. To such solutions incubated for $5 \mathrm{~min}$ at $37^{\circ}$, is added $400 \mu \mathrm{l}$ of methanol-water $(\mathrm{v} / \mathrm{v})$. After an additional 2 -min incubation at $37^{\circ}$. the optical density at $460 \mathrm{~nm}$ is imediately measured. (Coloration of the solution is silght ly labilized after addition of the methanol-water solution.) Blanks consist of the same

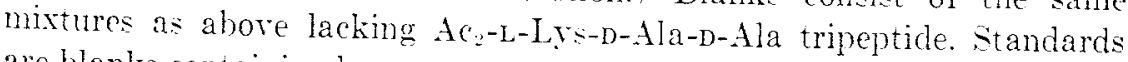
are blanks containing known amounts of $\mathrm{D}$-alanine.

\section{Assay Method for $\beta$-Lactamase}

DD-Carboxypeptidases-transpeptidases and $\beta$-lactamases react with penicillin. The reaction mechanisms and the reaction products are, howerer, different (see below). A complete s(paration between these two classes of enzymes is thus one major groal of the purification procedure of the DD-carboxypentidases-transpeptidases.

Standard Reaction for $\beta$-Lactamase

$$
\text { Benzylpericillin }+\mathrm{H}_{2} \mathrm{O} \rightarrow \text { benzylpenicilloic acid }
$$

$\beta$-Lactamase ('nit. One unit of $\beta$-lactamase catalyzes the hrdrolysis of $1 \mu$ mole of benzylpenicillin per minute at $30^{\circ}$ and under conditions of 'mzyme saturation by the suhstrate. The $K_{\text {m }}$ value of the $\beta$-lactamase from Streptomuces R39 is $70 \mu \mathrm{MI}$." That of the $\beta$-lactamase from Streptomyces R61 is not known.

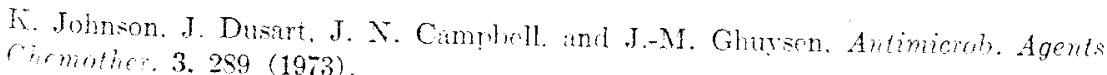


Rragcnts

Sodium acetate bufier. 1 ./ pH 3.6

Color reagent: equal rolumes of a water-soluble starch solution

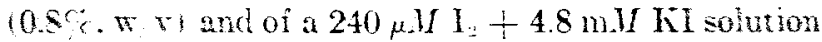

Procedurc. The following is a microscale adaptation of the technique of Norick and Dubnau." Benzylpenicillin $10.3 \mu$ molel is incubated with the enzyme preparation in $30 \mu \mathrm{l}$ (final volume) of $0.025 \mathrm{M}$ sodium phosphate buffer $\mathrm{pH}$ 7.0. The benzylpenicillin concentration in the mixture is $10 \mathrm{~m} . \mathrm{Y}$; hence. any $\beta$-lactamase with a $K_{\mathrm{m}}$ value for this antibiotic equal to or lower than $1 \mathrm{~m} M$ is saturated. After $10-30 \mathrm{~min}, 200 \mu l$ of $1 M$ acetate buffer and then $200 \mathrm{ul}$ of color reagent are added in sequence to the reaction mixture. After $10 \mathrm{~min}$ at $25^{\circ}$, the optical density of the solution is measured at $620 \mathrm{~nm}$. A control consisting of the same mixture sseking enzyme is incubated as above. Acetate buffer, the same amount of enzyme as used in the test, and finally the color reagent are added, and the optical density at $620 \mathrm{~nm}$ is determined. A decrease of the optical dersity of 0.1 corresponds to about 0.37 nmole of benzylpeniciloic aeid produced.

\section{Excretion of DD-Carboxypeptidase-Transpeptidase and $\beta$-Lactamase by Streptomyces R39 ${ }^{10}$}

Streptomyces R39 is grown for $24 \mathrm{hr}$ at $28^{\circ}$ with shahing in neptone medium. After two successive subcultures of increasing size, 100 liters of culture in exponential phase are used to inoculate 400 liters of the same peptone medium contained in a 500 -liter tank. This culture is grom at 28 for about $90-100 \mathrm{hr}$ with mechanical stirring $(120 \mathrm{mmm}$. and an airflow rate of $100 \mathrm{liters} / \mathrm{min}$ at an air pressure of $1.5 \times 10^{-} \mathrm{Pa}$. Silicone $\mathrm{A}$ emulsion (Dow Corning Co., Midland. Michigan; $20 \mathrm{ml}$ ) is used as antifoam. After centrifugation, the DD-carboxypeptidase activity in the euture fluid is about 2.5 munits $/ \mathrm{ml}$ or 1.5 munits $/ \mathrm{mg}$ of protein, and $\beta$-lactamase activity is 50 munits $/ \mathrm{ml}$. Similar results are obtained on a smaller seale by growing Streptomyces R39 in a New Brunswick Shaker inculator, in 1-liter flasks containing $400 \mathrm{ml}$ of peptone medium. Under both conditions, maximal do-carboxypeptidase actirity and maximal $\beta$-lactamase actirity occur almost simultaneously. Both activities then disappear progressively and are negligible after 6 dars. With time. the tro enzyme actirities increase and decrease independently of each other.

"P. P. Norick. J. Gen. Microbiol. 33, 121 (1963).

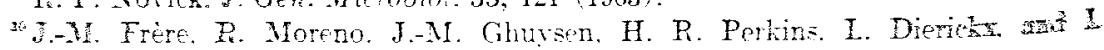
Delcambe, Bionhem. J. 143, 233 (1974). 
Excretion of DD-Carboxypeptidase Transpeptidase and $j$-Lactaniase by Streptomyces R61 ${ }^{11}$

Streptomyce R61 excretes larger anounts of its bo-carboxypeptidasetranspeptidase in glyerul-asein melium than in peptone nedium. The strain is grown at $28=$ in a $\mathrm{New}$ Brunswick Shaker incubator in 1-liter flasks containing $500 \mathrm{ml}$ of glycerol-casein medium. Often, the eultures exhibit two peaks of or-carboxypeptidase activity, the first one occurring after about $100 \mathrm{hr}$ (about $11 \mathrm{~mL} / \mathrm{ml}$ or $13 \mathrm{~mL} / \mathrm{mg}$ protein) and the second one after about 300 hr (about $18 \mathrm{~mL} / \mathrm{mll}$. To corresponding increase in mycelium production is observed. Lare amounts of free amino acids are present in the 100-200 hr cultures, and they subsequently disappear, suggesting that part of the lacterial population resumes growth from autolysis products. Inder the above growth conditions, Streptomyces $\mathrm{R} 61$ is a poor producer of exocellular $\beta$-lactamase. Its $\beta$-lactamase has not been studied.

\section{Purification of the DD-Carboxypeptidase-Transpeptidase from Streptomyces R39 (for 500 Liters of Culture Fluid) ${ }^{10}$}

Step 1. The enzrme is adsorbed from 500 liters of culture fluid on $3.7 \mathrm{~kg}$ (wet weight of DEAE-cellulose (MN 2100 DEAE. Macherey, Nagel and Co.. D-156 Düren. Germany equilibrated against 0.1 II Tris-HCl, pH 7.5. All subseruent steps are performed at 4 . The enzyme is eluted from the DEAE-cellulose by two subsequent treatments with 5 liters of $0.1 M$ Tris-HCl huffer. $\mathrm{pH} 7.5$. containing $1 \mathrm{~m} . \mathrm{M} \mathrm{rCl}_{2}$ and $0.1 \mathrm{M} \mathrm{NaCl}$. The solution is concentrated to 1.5 liter on Carbowax 4000 and solid ammonim sulfate is added to $50 \%$ saturation. The precipitate is discarded, and the $\mathrm{NH}_{4}, \mathrm{SO}_{4}$ concentration in the supernatant is increased to $90 \%$ saturation. The precipitate is collected by centrifugation, dissolved in $240 \mathrm{ml}$ of $0.1 \mathrm{M}$ Tris-HCl buffer. $\mathrm{pH} 7.7$. containing $1 \mathrm{mM}$ $\mathrm{MgCl}$, and the solution is dialyzed against the same buffer.

Step 2. After step 1. the enzyme solution is applied to a $600 \mathrm{ml}$ column of DEAE-cellutose $14 \mathrm{x} 48 \mathrm{cmi}$ equilibrated against $0.1 \mathrm{M}$ Tris-HCl buffer. $\mathrm{pH} 7.7$. containing $1 \mathrm{~m} . \mathrm{M} \mathrm{MgCl}$. and $0.1 \mathrm{M} \mathrm{TaCl}$. Some enzymically inactive proteins are eliminated by washing the colmom with the same buffer. and others are eluted by increasing the $\mathrm{XaCl}$ concentration in the buffer to $0.19 \mathrm{M}$. The resin is then treated with an increasing convex gradient of $\mathrm{XaCl}$ (mixing flask: $9 \overline{7} 0 \mathrm{ml}$ of $0.1 \mathrm{MT} \mathrm{Tris}-\mathrm{HCl}$ buffer $+1 \mathrm{mM}$

"M. Lerb-Bonille. J. Corette. J.-M. Ghuysen. J. Idezt. H. R. Perkins and M. Nieto, Rionleminty 10, $2163(1971)$. 
$\mathrm{MgCl}+0.19$ If $\mathrm{NaCl}$; upper flask: 0.1 .I Tris-HCl buffer $+1 \mathrm{mM}$ $\mathrm{MgCl}+0.28 \mathrm{M} \mathrm{XaCl}$. The enzyme is eluted at a $\mathrm{XaCl}$ concentration of about $0.24 \mathrm{M}$. The artive fractions are pooled ant concentrated to $20 \mathrm{mi}$ lw utrafiltration through Amicon LXI-10 membranes.

Steg 3. After step 2. the concentrated solution is filtered through a 400-mil column of Sephadex G-100 $(3 \times 45 \mathrm{~cm})$ previously equilibrated against $0.05 \mathrm{M}$ cacodylate- $\mathrm{HCl}$ buffer, $\mathrm{pH} 6.0$, containing $1 \mathrm{mM} \mathbf{M g C l}_{2}$ $+0.3 \mathrm{M} \mathrm{NaCl}$. The enzyme is eluted at a $K_{\mathrm{D}}$ value of 0.21 and weil separated from two yellow-brown pigments presenting $K_{\mathrm{V}}$, values of 0 0.02 and 0.72 , respectively). The active fractions are pooled $(90 \mathrm{ml})$.

Step 4. After step 3 , the solution is applied to a $30-\mathrm{ml}(2 \times 10 \mathrm{~cm})$ column of DEAE-Sephadex A-50, previously equilibrated against $0.05 \mathrm{M}$ cacodyate-HCl bufier, $\mathrm{pH} 6.0$, containing $1 \mathrm{mM} \mathrm{MgCl..}+0.3 \mathrm{M} \mathrm{XaCl}$. Fnzymirally inactive proteins are eliminated by washing the column first with $300 \mathrm{ml}$ of the same cacodylate- $\mathrm{HCl}-\mathrm{MgCl}$. buffer containing $0.4 \mathrm{I} \mathrm{YaCl}$ and then with $300 \mathrm{mI}$ of the same buffer containing $0.47 \mathrm{M}$ XaCl. The enzyme is then eluted with a convex gradient of $\mathrm{NaCl}$ (mixings flack $500 \mathrm{ml}$ of cacolylate-HCl buffer $+1 \mathrm{mM} \mathrm{MgCl}+0.47 \mathrm{M} \mathrm{NaCl}$; upper flask: cacodylate-HCl buffer $+1 \mathrm{~m} M \mathrm{MgCl}_{2}+0.5 M \mathrm{NaCl}$. A single peak of protein is obtained, which closely correlates with the activity. The active fractions are pooled and concentrated to $20 \mathrm{ml}$ by ultrafitration. The concentrated solution is filtered through the $400-\mathrm{ml}$ column of Semharlex $\mathrm{G}-100$. in $0.05 \mathrm{M}$ cacodvlate- $\mathrm{HCl}$ buffer. $\mathrm{pH} 6.0$. containing $1 \mathrm{~m} . \mathrm{MgCl}$ and $0.4 \mathrm{M} \mathrm{NaCl}$. The most active fractions of the eluted

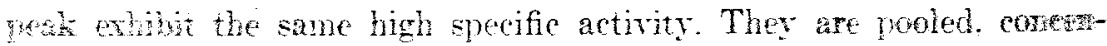
trated by ultrafiltration and dialyzed against $0.1 \mathrm{M}$ Tris-HCl buffer; $\mathrm{pH} 7.7$. containing $0.2 \mathrm{M} \mathrm{NaCl}$ and $0.05 \mathrm{M} \mathrm{MgCl}$. Ciraction $\mathrm{A}$. Table $\mathrm{I}$, specifir actirity: 17.1 units $/ \mathrm{mg}$ protein. The other fractions of the cluted neak have lower specific activities. They are pooled, concentrated. and dialyzed (fraction B, Table I). Fraction B (specific activity: 13 units ng protein, may be stored as it is and used for experiments that do not require an enzyme of absolute purity. Fraction $A$ behaves as a homoreneous protein in several analytical tests (see below). However, benzylmonicilin binding occurs at a ratio of 0.9 mole of henzylpenicinin per molo of enzyme. showing that some impurities are still present in the preparation (see below. Fig. 4 ).

step 5 . After step 4. to fraction A $11 \mathrm{ml}, 1.6 \mathrm{mg}$ of protein is added I mi of arctone previously cooled to $-20^{\circ}$. The mixture is stirred for 30 nin st $-20^{\circ}$ : the precinitate is collected by centrifugation at -5 and reflissolved in $1 \mathrm{~m}$ of 0.1 . $\mathrm{T}$ Tris-HCl bufier. $\mathrm{pH}-\overline{\mathrm{H}} \mathrm{-}$. containing $0.2 \mathrm{M}$ $\mathrm{XaCl}$ and $0.05 \mathrm{M} \mathrm{MgCl}$. At this stage benzymienilin binding aecurs it a ratio of $1.04=0.03$ mole of betzypeniohn ine mole of enzome

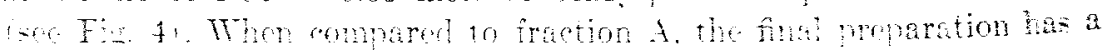




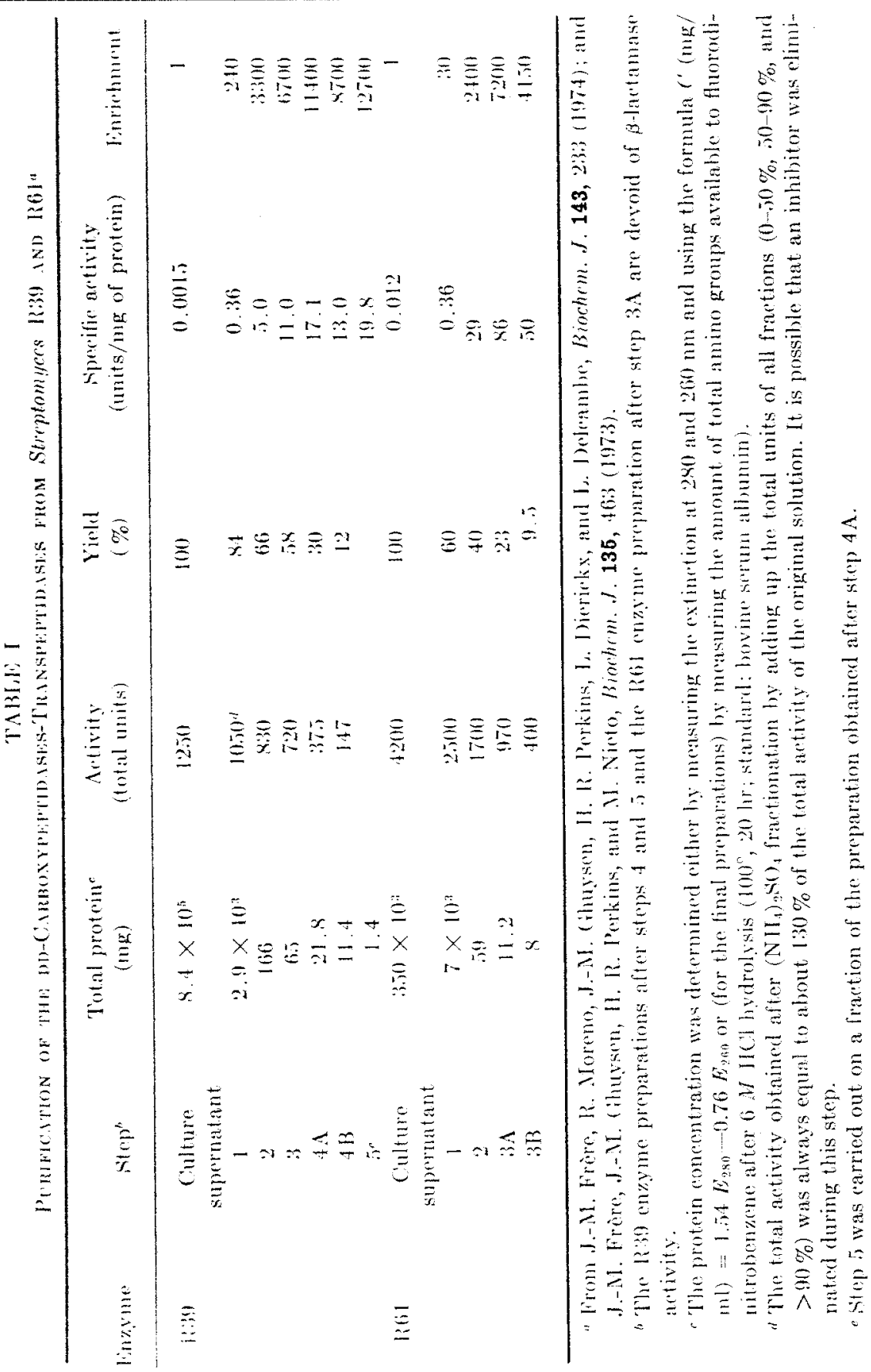




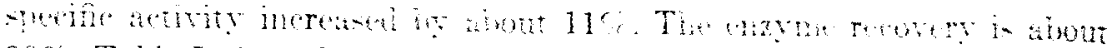
9or. Table I gives the totai reoveries and enroment- in spenfe activity after esch step of the purifeation procedure.

\section{Purification of the DD-Carboxypeptidase-Transpeptidase from Streptomyces R61 (for 400 Liters of Culture Fluid)}

The following is an adaptation of the technique of Frère $\epsilon$ al."2

Step 1. The enzyme is atisorbed from 400 liters oi culture fluid on $10 \mathrm{~kg}$ of Amberlite $\mathrm{XE} 64 \mathrm{H}^{-}$or $\mathrm{CG} 50 \mathrm{H}^{+}$by alliusting the $\mathrm{pH}$ to 4.0 with acetic acid. The Amberlite-atiorbed enzyme complex is suspended in 20 liters of cold $0.1 M \mathrm{~K}_{2} \mathrm{HPO}_{2}$, and the $\mathrm{pH}$ of the suspension is brought to 8.0 by dropwise addition of concentrated ammonia. The resin is removed by filtration, and the filtrate is ciarified by centrifugation. The adsorption of the conyme on the resin and its chution as well as all subsequent steps are performed at $4^{\circ}$. Solid $\mathrm{NH}_{4} \mathrm{I}_{2} \mathrm{SO}_{4}$ is addod to the cluted enzyme solution and the precipitate obtained at $40 \%$ saturation is discarded. Protein 1128 g. wet weight precinstated when the $\left(\mathrm{XH}_{4}, \mathrm{SO}_{4}\right.$ concentration is raised to $60 \%$ saturation is refisolved in 1 liter of $0.01 .17 \mathrm{Tris-HCl}$ buffer and dialyzed twiee against 50 liters of the same buffer. The dialyzed solution is stirred with $500 \mathrm{~g}$ wet weight of DEAE-cellulose previously equilibrated against 0.01 .I Tris-HCl buffer nH 8.0. The conzyme is cluted from the DEAE-cellulose by treating the resin, batchwise, with 1

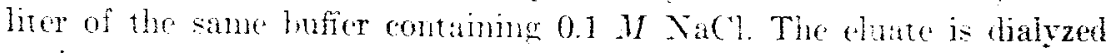
agrainst water.

Step? After -tely 1. the enzyme is arkorberl on a $600 \mathrm{ml}$ column of

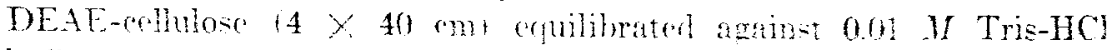
huffer $p H$ 8.0. The folumn is treated with an increang convex gradient of XaCl imixing flask. at con-tant rolume: $800 \mathrm{ml}$ ố 0.01 .11 Tris-HCl buffer: solution added: same buffer $+0.13 .1 / \mathrm{XaCl}$. The active fractions are poolest. coneentrated to $20 \mathrm{ml}$ hy ultrifiltration and filtered through

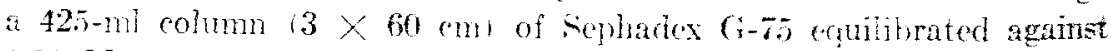
$0.01 Y$ cacolylate-HCl bufier $\mathrm{PH} 60$. The column is washed with the stme carodylate-HC? huffer and the cnzyme is cluted just iefore the main peak of protein. The actire frations are pookerl. At this stage the solution is still faintly redlow.

Step 3. After stepr 2 , the (nzymo is artiorbed on a $30-m$ column $22 X$ $10 \mathrm{~cm}$ of DEAE-Sphadex $A-50$ previously conulibrated against $0.01 \mathrm{U}$

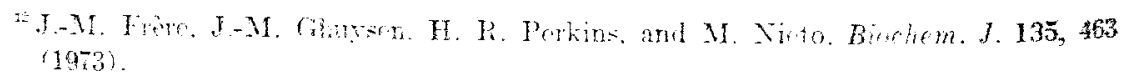




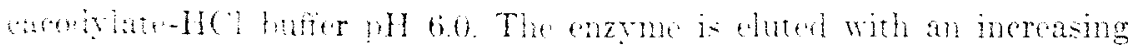

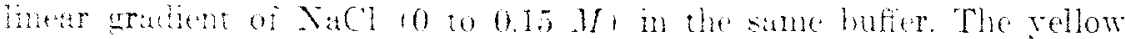
lighnent remains fixed on the top of the colmm. The active iractions in the center of the duted peak of protein exhibit a constant high specific artivity. They are pooled. concentrated to $10 \mathrm{ml}$ by ultrafiltation, and extensively dialyzed against water ypeparation $3 \mathrm{Al}$. The other fractions are treated likewise 1preparation 3B 1. Table 1 grives the total recoveries and enrichments in specific activity after each step of the purification procedure.

\section{Physicochemical Properties of DD-Carboxypeptidases-Transpeptidases from Streptomyces R39 and R61}

The properties described in the present paragraph together with the techniques of titration of the Streptomyces enzymes by $\beta$-lactam antibiotics: see below constitute the best available criteria of purity. For more details, sce Frère $\ell$ t al. ${ }^{10,1 ?}$

Diffusion Constant $1 \mathrm{H}_{2 n, w}$. Molecular Weight $4 \mathrm{MH}$. and Frictional Ratio if !.,

Buffers. The following bufiers are usert: 0.1 .M Tris-HCl. pH $7.7+$

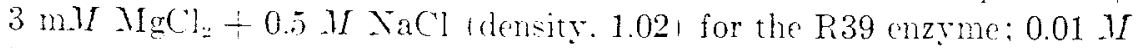
Tris-HCl $\mathrm{nH} 8.0-0.09$. I $\mathrm{XaCl}$ idenity. 1.002 । for the $\mathrm{P} 61$ enzyme.

Procedure. The enzyme solutions fdialyzed against the relerant buffert are andyzed by equilibrium sedimentation at a speed of $13.000 \mathrm{rpm}$ for $22 \mathrm{hr}$ at $20^{\circ}$ and initial protein concentration of $2-3 \mathrm{mg}$ m. The rates of diffusion are measured by plotting $A^{*} \| / H-F=1$ against time $A=$ area and $H=$ maximum height of the poak: $F=$ total enlargement usedi. The apparent molecular weights $\left(M Y_{\text {mpp }}\right.$ ) at any point $x$ of the solution column iabout $2 \mathrm{~mm}$ longi are calculated according to the countion

$$
Y_{\mathrm{n}+1)}=\left[R T /(1-\bar{\imath} \rho) \omega^{2}\right]\left(1 / C_{x}\right)(r / d x)
$$

where $\bar{v}=$ partial specific rolume (supposed to be egual to $0.75 \mathrm{~cm}^{3}$ $\mathrm{s}^{-1}$.,$\rho=$ density of the solvent (see abore); $C=$ protein concentration at point $x$. The molecular weights are obtained by plotting $1 / \mu_{\text {pr }}$ against concentration at $0.1-\mathrm{mm}$ intervals of the column. The results are given in Table II. 
'TABL.L' II

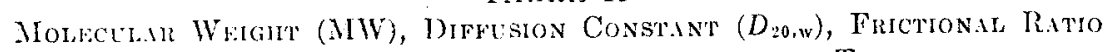

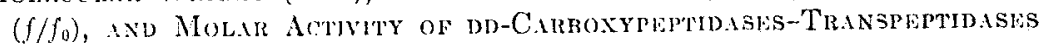
From Streptomyers li39 AN R61"

\begin{tabular}{lcccc}
\hline Enzyme & $\mathrm{NW}$ & $\left(\times 10^{-3}\left(\mathrm{~cm}^{2} \mathrm{sec}^{-1}\right)\right.$ & $j / f_{0}$ & $\begin{array}{c}\text { Molar activity } \\
\left(\mathrm{min}^{-1}\right)\end{array}$ \\
\hline R390 & 53,500 & 7.88 & 1.07 & 1050 \\
R61 & 37,000 & 8.45 & 1.12 & 3300 \\
\hline
\end{tabular}

"From J.-M. Frìre, R. Moreno, J. M. Ghuysen, H. R. Perkins, L. Dieriekx, and L. Delambe, Biochem. J. 143, 23: (1974); and J.-M. Frère, J.-M. Ghuysen, IT. R. Perkins, and M. Nieto, Bioch"m. J. 135, 463 (1973).

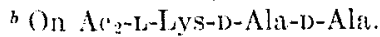

\section{Remarks}

1. With a homogeneous protein, the plot of $1 / M_{\text {an }}$ vs $C_{\text {. }}$ during sedimentation equilibrium gives rise to a line parallel to the abscissa. Figures $1 \mathrm{~A}$ and $1 \mathrm{~B}$ show the results obtained with the R61 cnzyme after various steps of purification, and Fig. $1 \mathrm{C}$ with the purified R39 enzyme.

2. When equilibrium sedimentation of the phified R39 enzyme is carried out in the same Tris- $\mathrm{HCl}-\mathrm{MgCl}$, buffer as above except that the $\mathrm{NaCl}$ concentration is $0.2 \mathrm{M}$ instead of $0.5 \mathrm{M}$, the plot of $1 / M_{\text {ipp }}$ vs concentration gives a line with a slope of $-1.1 \times 10^{-4}$ (with the same coordinates as in Fig. 1). This is because the R39 protein aggregates at low ionic strength.

Sephadex Filtrations. Filtrations are carried out on $1.5 \times 65 \mathrm{~cm}$ columns of Scphadex (a-100, using dextran blue, ovalbumin, myoglobin, bovine scrum albumin, and chymotrypsinogen as molecular weight standarls. In $0.01 M$ Tris- $\mathrm{HCl}$ buffer, $\mathrm{pH}$ H 8.0 , the apparent molecular weight of the R01 enzyme is about 38,000 . The apparent molecular weight of the R39 enzyme decreases as the ionic strength of the buffer increases. Ionic strengths equal to or higher than $0.07 \mathrm{M}$ and ionic strengths lower than $0.07 M$ are obtained with $0.1 M$ and $0.01 M$ Tris-HCl buffers, $\mathrm{pH}$ 7.7, respectively, supplemented with the appropriate amount of $\mathrm{NaCl}$. The apparent molccular weight is over 100,000 at $I=0.008 M, 86,000$ at $I=0.025 M, 70,000$ at $I=0.070 M$, and about 60,000 at $I>0.20 M$.

\section{Analytical Polyacrylamide Gel Electrophoresis}

In the Absence of Sodium Dorlecyl Sulfate $(S D S)$. The gels $(6 \times 71$ mm) ane prepared with $7 \%$ acrylamile and $0.18 \% N, N^{\prime}$-methylenebisa- 

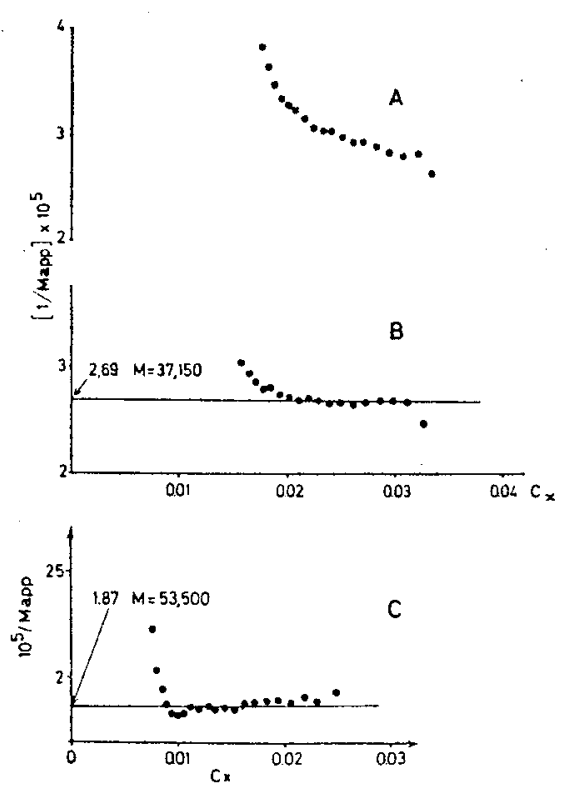

Fig. 1. Reciprocal of the apparent molecular weight $\left(1 / M_{u \mid 13}\right)$ of Streplomyces vis-curboxypeptidases-transpeptidases as a function of the concontration in the

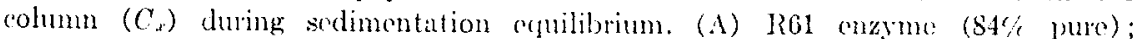
(B) R61 enzyme after step $3 A$ of purification; (C) IR39 mzyme after step 5 of purifation. Expcriments are carried ont in $0.01 \mathrm{M}$ Tris-MCl bufer, ph s.0, will ionie strength adjusted to 0.1 with $\mathrm{NaCl}$ for the $\mathrm{R} 61$ onzyme and in $0.1 \mathrm{M}$ Tris-HCl buffer $p \mathrm{H} 7.7+3 \mathrm{~m} M \mathrm{MgCl}_{2}$ and $0.5 \mathrm{M} \mathrm{NaCl}$ for the $\mathrm{R} 39$ enzyme. For other conditions, sec text and the following anticles, from which fig. 1 is reprinted by courtesy of the Biochemical Society. J.-M. Frem, R. Moneno, J-M. (ihuysen, H. R. Perkins, L. Dierickx, and I. Doleambe, Biochem. J. 143, 233 (1974); J.-M. Frère, J.-M. Ghuren, II. R. Porkins, and M. Nielo, Birchem. J. 135, 163 (1973).

crylamide in $0.375 \mathrm{M}$ Tris-HCl buffer, $\mathrm{pH} 8.4$, and polymerized in the presence of $0.08 \%$ ammonium persulfate and $0.03 \% \quad N, N, N^{\prime}, N^{\prime}$-tetramethylethylenediamine. The electrolyte is $0.025 \mathrm{M}$ (in Tris) Tris-glycine buffer pH 8.4. In some eases, gels are submitted to prior electrophoresis for $3 \mathrm{hr}$ at $4 \mathrm{~mA} / \mathrm{gel}$ (preruns). Electrophoreses of the samples $(25 \mu \mathrm{g}$ of protein) are performed for $135 \mathrm{~min}$ at room temperature and at $3 \mathrm{~mA} / \mathrm{gel}$. Quartz tubes are used so that the same gel ean be scamed at $280 \mathrm{~nm}$ and then removed from the tube and slieed into seetions (which are eluted and assayed for DD-carboxypeptidase activity). Parnllel gels are stained with Coomassie blue as usual. Irrespective of the procedure used for detection, the enzymes give a single band. On gels that are not perm, migrations toward the anote are $3.5 \mathrm{~cm}$ for the $R 61$ anzyme, $4.4 \mathrm{~cm}$ for the $R 39 \mathrm{~cm}$ zyme, and $4.4 \mathrm{~cm}$ for bromophenol blue. On gels that are prerm, mi- 
grations toward the anode are $4.3 \mathrm{~cm}$ for the R39 enzyme and 6.4 for bromophenol blue.

In the Presence of SDS. Electrophoreses are performed at room temperature in $0.01, M$ sodium phosphate, $\mathrm{pH} 7.1$, in the presence of $0.1 \%$ $(\mathrm{w} / \mathrm{v})$ SIS (Veber and Osborn ${ }^{13}$ ) with prior incubations of the proteins for 15 hr at $37^{\circ}$ in the same phosphate buffer containing $1 \%(\mathrm{w} / \mathrm{v})$ SDS, with or without the addition of 2 -mereaptoethanol $(1 \%$, final volume). Fach enzyme gives rise to a single band and the mobilities (when compared to that of -imilarly trated standard proteins) indicate a molecuhar weight of $56,000 \pm 3000$ (7 determinations) for the R39 enzyme and of $39,000 \pm 1600$ (4 determinations) for the R61 enzyme. These values are unaltered when mereaptoethanol is omitted during pretreatment of the proteins with SDS. Fach of the R39 and R61 enzymes thus consists of one single polypeptide chain.

Electrofocusing. The gels $(6 \times 0.5 \mathrm{~cm})$ contain $2.5 \%$ carrier ampholytes (p) $13-6), 7 \%$ aerylamide, $0.18 \% N, N^{\prime}$-methylenchisacrylamide, and $0.08 \%$ ammonium persulfate. For other conditions, sce Frère et al. ${ }^{22}$ The R61 cuzyme has an iscelectric point of $4.8 \pm 0.14$ (4 determinations). Bocause of the high tendency of the R39 enzyme to aggregate at low ionic strength, its isoclectric point cannot be determined by this technique. In normal $\mathrm{gel}$ elcetrophoresis at $\mathrm{pH}$ 8.4, the R39 enzyme is more anionic than the R61 enzyme (see above).

Spectra. All spectra are determined at $25^{\circ}$ in $0.1 M$ Tris- $\mathrm{HCl}$ buffer, pH $7.7,+0.05 M \mathrm{MgCl}_{2}+0.2 M \mathrm{NaCl}$ for the R39 enzyme and in $1 \mathrm{mM}$ Tris-HCl buffer, $\mathrm{pH}$ 7.4, for the $\mathrm{R} 61$ enzyme.

Utraviolet Absorption. $E_{1 \% \mathrm{~m}}^{1 \%}$ values at $280 \mathrm{~nm}: 9.7 \mathrm{for}$ the $\mathrm{R} 39 \mathrm{cnzymo}$ and 10.0 for the R61 mzyme.

Fluorescence Emission. Excitation at $285 \mathrm{~mm}$ produces an emission maximum at $340 \mathrm{~nm}$ with the $R 39$ enzymc $^{10}$ and at $320 \mathrm{~nm}$ with the $R 61$ (nizyme. ${ }^{\text {it }}$

Circular Dichroism. Circular diehroism spectrum of the R61 enzyme is given by Nieto et al. ${ }^{1+4}$

Animo Acid Compositions. The compositions are shown in Table III. By summing the residue mole percentages of the hydrophilic amino acids plus one half of the mole percentages of the intermediate class, ${ }^{15}$ the polarity index then found is 39.7 for the R39 enzyme and 40.5 for the R61 enzyme.

${ }^{13}$ K. Wober and M. Osborn, J. Biol. Chem. 244, 4406 (1969).

${ }^{1}$ M. Nieto, H. R. Porkins, J.-M. Frère, and J.-N. Ghuysen, Biochem. J. 135, 493 (1973).

${ }^{15}$ R. A. Capaldi and C. Vanderkooi, Proc. Natl. Acad. Sci. U.S.A. 69, 930 (1972). 
TABLI: III

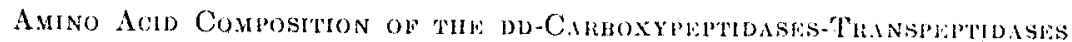
From Streptonuyces Ri39 and R61

\begin{tabular}{|c|c|c|c|c|c|c|}
\hline \multirow[b]{2}{*}{ Residue } & \multicolumn{3}{|c|}{ Strain R:so } & \multicolumn{3}{|c|}{ Strain 1261} \\
\hline & $\begin{array}{l}\text { Residues/ } \\
\text { enzyme } \\
\text { molereule } \\
(\mathrm{NIW}= \\
53,300)\end{array}$ & $\begin{array}{l}\text { Total } \\
\text { mass }\end{array}$ & $\begin{array}{c}\% \text { (in } \\
\text { number) }\end{array}$ & $\begin{array}{l}\text { Residues/ } \\
\text { enzyme } \\
\text { molecule } \\
(\mathrm{MW}= \\
38,000)\end{array}$ & $\begin{array}{l}\text { Total } \\
\text { Illatss }\end{array}$ & $\begin{array}{c}\% \text { (in } \\
\text { number) }\end{array}$ \\
\hline Asp & 50 & 5750 & $9 . \overline{5}$ & 38 & $4: 370$ & 10.9 \\
\hline Thr & 34 & $34: 34$ & 6.4 & 38 & 3835 & 10.0 \\
\hline Ser & 38 & 3306 & 7.2 & 29 & 2523 & 8.3 \\
\hline Gilu & 57 & 7353 & 10.8 & 23 & 3612 & 8.0 \\
\hline Pro & 25 & 2425 & 4.7 & 11 & 1067 & 3.1 \\
\hline Gly & $66^{\circ}$ & 3762 & 12.5 & 32 & $182 \cdot 1$ & 9.1 \\
\hline Ala & 82 & 5822 & $1 \pi . \pi$ & 34 & 2114 & 9.7 \\
\hline $\mathrm{Cys}^{n}$ & 2 & 204 & 0.37 & $: 3$ & 300 & 0.86 \\
\hline $\mathrm{Val}$ & 51 & .5049 & 9.7 & 30 & 2970 & 8.0 \\
\hline Met & 3 & 393 & 0.57 & 6 & 786 & 1.71 \\
\hline He & 10 & 1130 & 1.9 & 9 & 1017 & 2.6 \\
\hline Iseu & 50 & 56.50 & 9.5 & 33 & 3729 & 9.4 \\
\hline Tyr & 10 & 16.30 & 1.9 & 13 & 2119 & 3.7 \\
\hline Phe & 11 & 1617 & 2.1 & 12 & 176.1 & 3.4 \\
\hline $\mathrm{H}$ is & 9 & 1233 & 1.7 & 8 & 1006 & 2.3 \\
\hline Lys & i) & 640 & 0.95 & 8 & 1024 & 2.3 \\
\hline Arg & 19 & $294 i j$ & 3.6 & 11 & 2170 & 4.0 \\
\hline \multirow[t]{2}{*}{$\operatorname{Trp}{ }^{a}$} & 6 & 1122 & 1.1 & 4 & 748 & 1.14 \\
\hline & $\overline{528}$ & $\overline{534 \times 33^{3}}$ & & 350 & 373993 & \\
\hline
\end{tabular}

"Ilalf-eystine is measured as cysteic acid alter performie aciel oxidation of $200 \mu \mathrm{\mu g}$ of protcin. Tryptophan is measured from the UV' spectrum in alkali.

${ }^{b}$ Taking into arcount a mass of 18 for $\mathrm{II}_{2} \mathrm{O}$.

\section{Interaction between DD-Carboxypeptidases-Transpeptidases from Streptomyces R39 and R61 and $\beta$-Lactam Antibiotics ${ }^{16-18}$}

The reactions and propertics that are described below are relevant to experimental conditions where the enzymes, by themselves, are perfectly stable, i.c., in $0.1 M$ Tris-HCl buffer, $p \mathrm{H} 7.7$, $+0.05 M \mathrm{MgCl}_{2}+$

"J.-M. Frère, J.-M. Ghuysen, P. E. Reynolds, R. Moreno, and II. R. Perlins, Biochem. J. 143, 241 (1971).

${ }^{13}$ J.M. Frère, M. Lcyh-Bonille, J.-M. Ghuysen, and Ir. R. Perkins, Em. J. Biochem. 50, 203 (1974).

${ }^{18}$ J.-M. Frère, J.-M. Ghuysen, and M. Iwatzubo, Eur.J. Biochem. 57, 343 (1975). 
$0.2 M \mathrm{NaCl}$ for the R39 enzyme and in $5-10 \mathrm{mM}$ sodium phosphate buffer, pH 7.0, for the R61 enzyme.

Reaction. At room temperature, the $\mathrm{R} 39$ and $\mathrm{R} 61$ enzymes react readily with $\beta$-lactam antibioties to form equimolar and inactive antibioticcnzyme complexes. When maintained at $37^{\circ}$, these complexes undergo spontancous breakdown during which the enzyme is reactivated whereas the antibiotic molecule is released in a chemically altered form. The reactions occur according one of the two following possible mechanisms:

$$
\mathrm{E}+\mathrm{P} \stackrel{K}{\rightleftharpoons} \mathrm{EP}^{\stackrel{k_{3}}{\rightarrow}} \mathrm{EP}^{*} \stackrel{k_{4}}{\rightarrow} \mathrm{E}+\mathrm{X}
$$

or

$$
\mathrm{H}+\mathrm{P} \underset{k_{2}}{\stackrel{k_{1}}{\rightleftarrows}} \stackrel{k_{3}}{\stackrel{k_{3}}{\rightarrow}} \stackrel{k_{1}}{\stackrel{k_{1}}{\rightarrow}} \mathrm{E}+\mathrm{X}
$$

$\mathrm{E}=$ active enzyme; $\mathrm{P}=$ intact antibiotic molecule; $\mathrm{EP}=$ inactive antibiotic-enzyme complex; $\mathrm{EP}^{*}=$ inactive complex after isomerization of the antibiotic molecule; $X=$ released and chemically altered antibiotic molecule. Mcchanism (3) is the simplest one that accounts for all the experimental facts so far accumulated. Table IV gives the values of the various constants $(K=$ dissociation constant of complex EP) for the reactions between the R61 enzyme and various $\beta$-lactam antibiotics. Table IV also gives the half-lives of various $\mathrm{EP}^{*}$ complexes formed with both R61 and R39 enzymes. For more details, see Frère et al. ${ }^{18}$

Effects on $\beta$-Lactom Antibiotics. Reaction of benzylpenicillin with both R39 and R61 enzymes ${ }^{16,17}$ yields complexes that subsequently release a compound $\mathrm{X}$ that is neither benzylpenicillin nor benzylpenicilloic acid (nor a product arising from a spontaneous degradation of free benzylpenicillin). Unlike benzylpenicilloic acid, compound $\mathrm{X}$ cannot be titrated with the iodine reagent (see assay method for $\beta$-lactamase).

Reaction of cephaloridine with the R39 cnzyme ${ }^{16}$ causes a $70 \%$ decrease of the absorbance at $250 \mathrm{~nm}$, as observed when the $\beta$-lactam ring of cephaloridine is hydrolyzed by $\beta$-lactamase. Reaction of cephalosporin $87-312$ (sce below) with the R39 enzyme ${ }^{16}$ causes a shift of the absorption maxinum of the antibiotic molecule from 386 to $482 \mathrm{~nm}$. The absorption spectrum of the R39 enzyme-cephalosporin $87-312$ complex is identical to that of cephalosporin 87-312 hyclrolyzed by $\beta$-lactamase (Fig. 2). In both cascs, the rutio $\epsilon_{3 * 2} / \epsilon_{38 ;}$ is equal to 2.40 .

The Ro1 cnzyme-cephalosporin 87-312 complex, once formed, has a ratio $\epsilon_{15:} / \epsilon_{356}$ equal to $1.20 .^{13}$ This value is considerably lower than normally expected if the $\beta$-lactam ring were hydrolyzed as with $\beta$-lactamase. The difference spectrum between the R61 enzyme-cephalosporin 87-312 


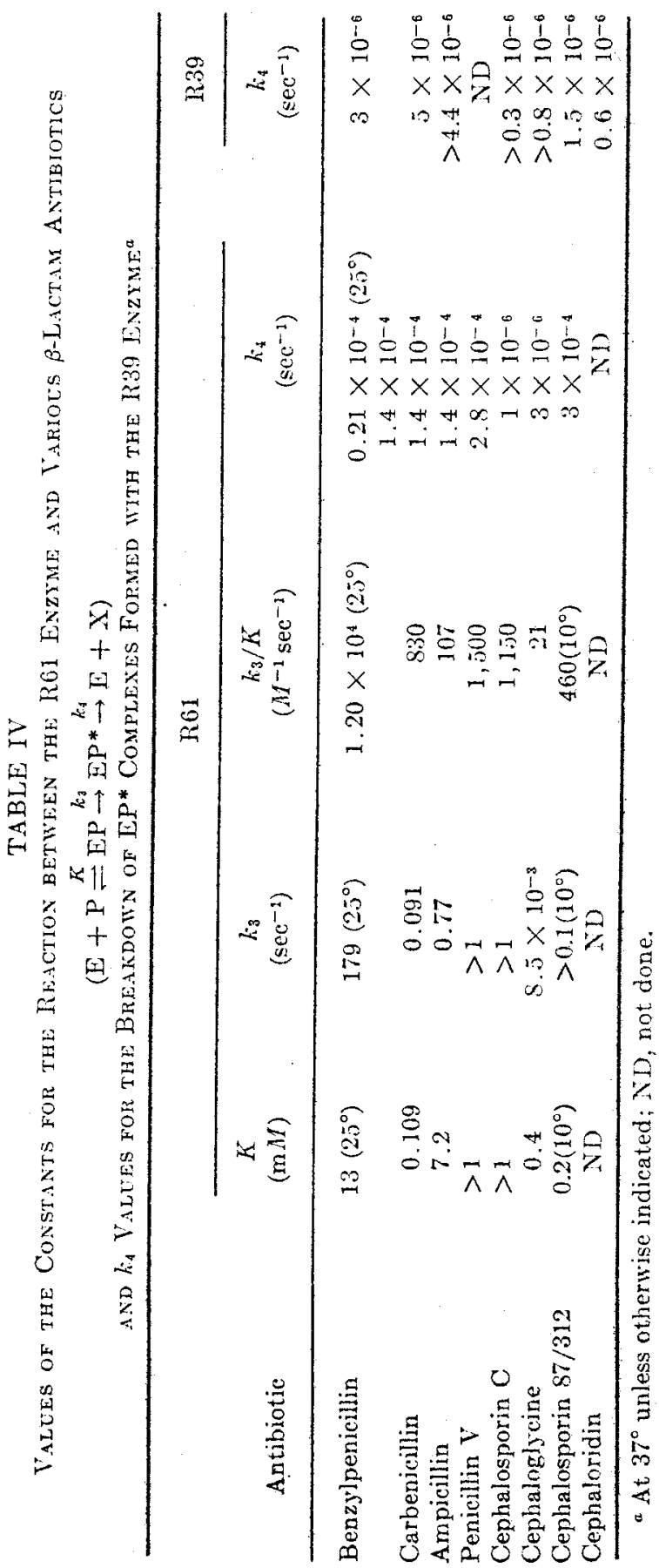




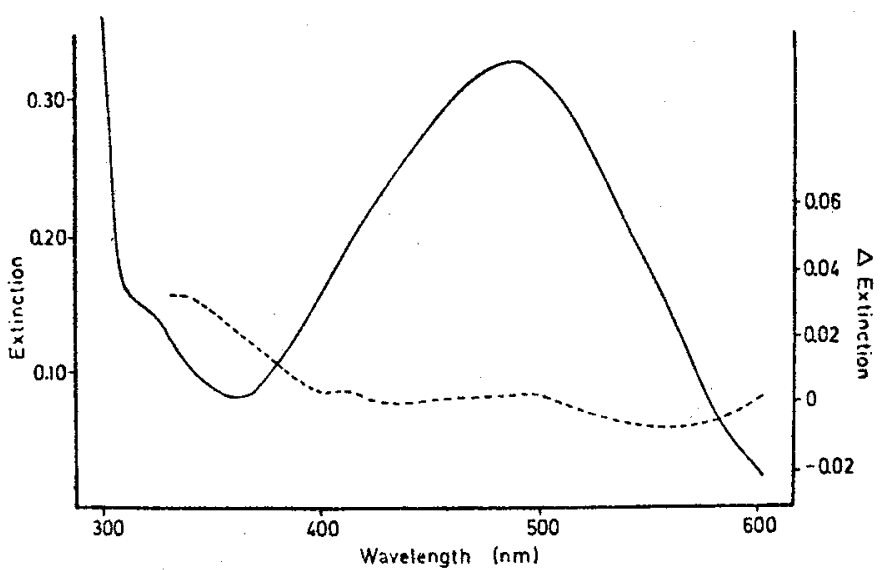

IIG. 2. Absorption spectrum of cophalosporin 87-312 after treatment with the Stieplomyces R39 cnzyme and with $\beta$-lactamise. - Solution containing 15.5 nmoles of Streplomyces $\mathrm{R} 39$ protein in $0.4 \mathrm{ml}$ of Tris- $\mathrm{NaCl}-\mathrm{M}$ oCl. buffer was mixed with $0.2 \mathrm{ml}$ of a $67.7 \mu .1 /$ solution of eeplusosporin $87-312$. The mixture was incubated for 5 min at room temperature before the absorption spectrum was determined. ---, Difference spectrum between cephalosporin treated with Streptomyces R39 enayme and ephatosporin treated with $\beta$-hatetamase. Note the change of scale. Solution containing 6 units of $\beta$-lactimase in $0.4 \mathrm{ml}$ of Tris- $\mathrm{NaCl}-\mathrm{MgCl}_{2}$ buffer was mixed with $0.2 \mathrm{ml}$ of the same solution of ephalosporin $87-312$ as above. The mixture was incubated at $37^{\circ}$ unt il the allsobhance at $482 \mathrm{~nm}$ was a maximum (less than $5 \mathrm{~min}$ ). Reprinted by courtesy of the Biochemical Society from J.-M. Frère, J.-M. Ghuysen, P. F. Reynolds, R. Moreno, and H. R. Perkins, Biochem. J. 143, 241 (1974).

complex, once formed, and the same concentration of cephalosporin 87312 hydrolyzed by $\beta$-lactamase shows extrema at 390 and $525 \mathrm{~nm}$ (Fig. 31 . Incubation at $37^{\circ}$ of the R61 cnzyme-cephalosporin 87-312 complex results in the reactivation of the cnzyme and in a parallel decrease of the two extrema in the difference suectrum (Fig. 3).

Molar Activity on Benzylpenicillin. On the basis of the $k_{1}$ values for the breaklown of the EP* complexes (Table IV), the specific activity (in equivalents of $\beta$-lactamase unit and at $37^{\circ}$ ) of the R61 enzyme is $2.2 \times 10^{-1}$ unit per milligram of protein and that of the R39 enzyme is $0.35 \times 10^{-5}$ unit per milligram of protein. Molar activity (in $\mathrm{min}^{-1}$ ) is $8.4 \times 10^{-3}$ for the R61 cnzyme and $2.1 \times 10^{-4}$ for the R39 enzyme. These values are to be compared with molar activities on Ac-L-Lys-D-Ala of $3300 \mathrm{mml} 1050$, respectively.

Eflerts on Circular Dichroism (CD) and Flworescence of Streptomyces Enzymes. Tho circular diehroism and fluoresence spectru of the R39 enzyme are not modified by benzylponicillin.

The neir UV CD spectrum of the R61 cnzyme is affected by benzylponicillin whereas the peptide region of the CD spectrum in the far UV 


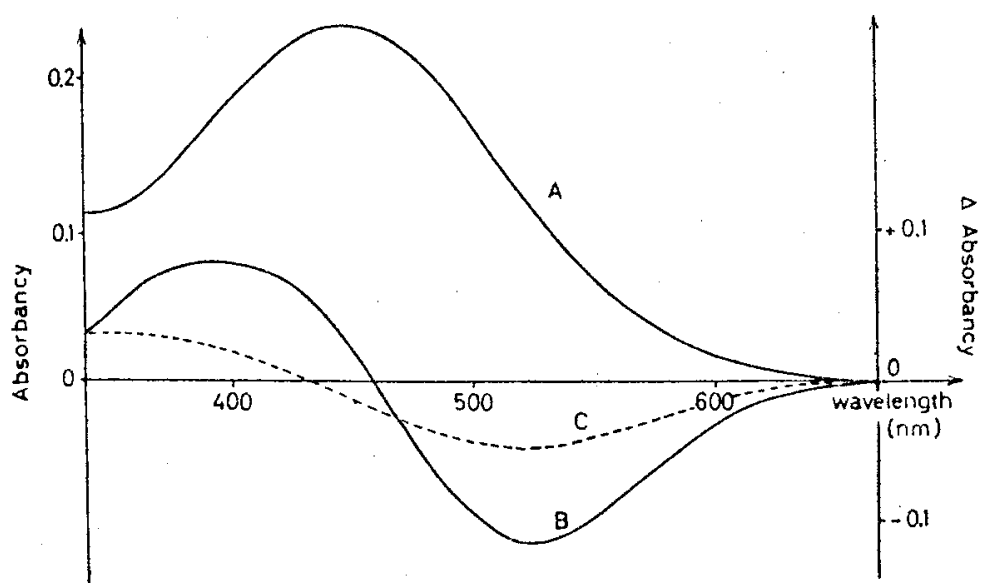

Frg. 3. Absorption spectrum of cephalosporin 87-312 after treatment with the Streplomyces R61 enzyme and with $\beta$-lactamase. The spectra were recorded with $0.5 \mathrm{ml}$ curettes and an optical pathway of $1.0 \mathrm{~cm}$. Bulfer: $5 \mathrm{~m} M$ soilium phosphate pH 7.0. For other conditions, sce text. Curve A: Absorption spectrum of a freshly prepared $R 61$ enzyme-cephalosporin 87-312 complex. Conecntration of the complex, $15 \mu$. I. Curve B: Difference spectrum between the froshly propared R61 crayneephalosporin 87-312 complex and an equivalent amount of eeplanlosiporin 87-312 hydrolyzed by penicillinase. The solutions contained 7.5 nanoequivalents of cephatosporin 87-312 (either combined with the enzyme or hydrolyzed by penicillinase) in a final volume of $500 \mu \mathrm{l}$. Curve $\mathrm{C}$ : Difference spectrm between the same complex as in $\mathrm{B}$, maintained for $60 \mathrm{~min}$ at $37^{\circ}$, and an equivalent amount of explatosporin 87-312 hydrolyzed by penieillimase. Note that after 60 min at $37^{\circ}, 65 \%$ of the initially inhibited activity had recovered and, parallel to this, the intensities of the two extrema in the difference spectrum had decreased to $40 \%$ of the oliginal values. Reprinted by courtesy of the Federation of Luropean Bionemical Societies from J.-M. Frère, M. Leyh-Bouille, J.-M. Ghuysen, and H. R. Prikins, Lur. J. Biochem. 50,203 (1974).

remains unchanged." The overall change in $\mathrm{CD}$ is too small, and the concentration of enzyme too high, to be convenient for quantitative work.

Saturating concentrations of benzylpenicillin decrease the fluoreseence emission at $320 \mathrm{~nm}$ of the R61 enzyme by $25-30 \% .^{1+}$ Quenching of the fluorescence of the cnzyme (concentration, $0.76 \mu M$ ) in the presence of an equimolar amount of benzylpenicillin is not immediate and is maximal after $5-10 \mathrm{~min}^{14}$

\section{Titration of DD-Carboxypeptidases-Transpeptidases from Streptomyces R39 and R61 by $\beta$-Lactam Antibiotics}

Buffers. Tris-IICl buffer, $0.1 M, \mathrm{pH} 7.7+0.2 \mathrm{M} \mathrm{NaCl}+0.05 M$ $\mathrm{MgCl}_{2}$ (Tris- $\mathrm{NaCl}-\mathrm{MgCl}$. buffer) is used for the $\mathrm{R} 39$ enzyme, and 5-10 mM sodium phosphate buffer is used for the R61 cnzyme. 


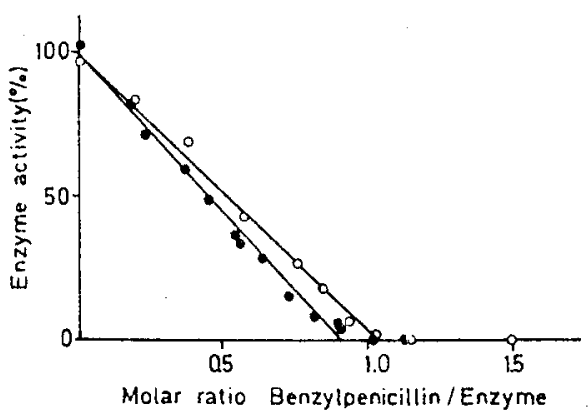

FIti, 4. Titration of the Streplomyces R39 protein with benzylpenicillin, based on the inhibition of enzyme actirity.

- Enzyme after step $4 A$ of purification; $\mathrm{O}-\mathrm{O}$, mzyme after step 5 of purification. For conditions, see text. Reprinted hy courtesy of the Biochemieal Society from J.-M. Frere, J.-M. Chuysen, P. F. Reynohls, R. Moreno, and H. R. Porkins, Biochem. J. 143, 241 (1974).

Antibiotics. Benzylpenicillin and cephaloridine solutions are made fresh, by weight, in the appropriate buffer.

Cophalosporin 87-312 [i.c., 3-(2,4-dinitrostyryl)-(6R-7R)-7-(2-thieny]acctamido)-ceph-3-em-4-carboxylic acid, F-isomer $]^{19}$ solutions (usually $0.1 \mathrm{~m} / I$ ) are made by dissolving the antibiotic in $1 \mathrm{ml}$ of dimethylformamide, and the volume of the solution is adjusted to $250 \mathrm{ml}$ with the appropriate buffer. The final concentration is estimated by measuring the extinction at $386 \mathrm{~nm}$ and by using a molar cocfficient $\epsilon_{386}^{1 \mathrm{~cm}}$ of 17,500 .

Titration of the R39 and R61 Enzymes with Benzylpenicillin Based on the Disappearance of Enzyme Activity. ${ }^{16}$ Samples of a $5 \mu M$ benzylpenicillin solution (either in Tris- $\mathrm{NaCl}-\mathrm{MgCl}$ or phosphate buffer) are added stepwise to $100 \mu \mathrm{l}$ of a solution containing 0.3 mmole of either R39 or R61 cnzyme in the relevant buffer. After cach addition, the solution is mixel and maintained at room temperature for $5 \mathrm{~min}$; a sample (2-10 $\mu 1)$ is removed and used for the measurement of the residual DD-carboxypeptidase activity (by incubating the sample with $\mathrm{Ac}_{\mathrm{g}}-\mathrm{L}-\mathrm{L}$-ys-D-Ala-D-Ala for $10 \mathrm{~min}$ at $\left.37^{\circ}\right)$. After correction for the decrease in the amount of enzyme owing to the removal of samples and, in the ease of the R61 enzyme, after correction of the estimated residual enzyme activity (see bolow), the end points of the titration occur at a molar ratio of benzylpenicillin to enayme of $1: 1$ (Fig. 4).

Becatise of the short half-life of the R61 enzyme-benzylpenicillin complex (Table IV), breaklown of the complex and reactivation of the

\footnotetext{
"C. O'Callaghan, A. Morris, S. $\Lambda$. Kirhy, and A. H. Shingler, Antimicrob. Agents,
} Chemother. 1, 283 (1972). 
enzyme oceur during estimation of residual enzyme activity at $37^{\circ}$. The cxact residual activity ${ }^{17}$ (as percent, after addition of $x$ moles of antibiotic) is cqual to

$$
\frac{\left(A_{\mathrm{m}} / A_{0}\right)+\left[\left(1-e^{-k_{4} t}\right) / k_{1} l\right]-1}{\left(1-e^{-k_{4} l}\right) / k_{t} l}
$$

where $A_{m}$ is the amount of hydrolyzed tripeptide measured in each case, $A_{0}$ the amount of hydrolyzed tripeptide obtained with the same amount of uninhibited cnzyme, and $t$ the duration of the incubation with the tripeptide (i.e., 600 see). For the $k_{+}$value, see Table IV.

Breakdown of the R61 enzyme-antibiotic complex formed at the begimning of the titration also occurs during the subseguent steps of the titration. Since the titration is carried out at $22^{\circ}$, however; the error thus introduced is negligible.

Titration of the R61 Enzyme with Benzylpenicillin Based on Fluoresence Quenching." Binding of benzylpenicillin to the R(i1 (nzyme ean be followed by the fuoresecnce (quenching at $320 \mathrm{~mm}\left(\Delta F_{320}\right)$. Sumples of a $0.232 \mathrm{~m} / \mathrm{M}$ solution of benzyluenicillin in $10 \mathrm{~m} M$ soulium phosphate buffer $\mathrm{pH} 7.0$ are added stepwise at $25^{\circ}$ to $2 \mathrm{ml}$ of a solution rontaining 1.4 mmoles of R61 enzyme in the same buffer. Realings are taken $10 \mathrm{~min}$ after each addition to allow time for completion of the reaction. Wxeitation is at $273 \mathrm{~mm}$. Extrapolation of the two lines of the curve intersect at a point where the molar ratio of benzyluenicillin to enzyme is $1: 1$ (Fig. 5).

Titration of the R39 Enzyme with ("ephaloridine." Samples of $0.5 \mathrm{mM}$ cephaloridine in Tris- $\mathrm{NaCl}-\mathrm{MgCl}$, buffer are ahlect stuwise, at room temperature, to $0.4 \mathrm{ml}$ of a solutien containing 6.5 moles of $R 39$ enzymo in the same buffer. After cach addition, the extinction of the solution is measured at $250 \mathrm{~nm}$ and the DD-carboxypeptidase is mensured in a $2-\mu \mathrm{l}$ sample. A plot of the inereased extinetion of the solution at $250 \mathrm{~mm}$ as a function of the amount of cephaloridine added yickels two lines intersecting at a point. On the basis of these data and the determination of enzyme activity, the end points of the reaction occur at a molar ratio of cephaloridine to cuzyme of $1: 1$. (For illustration, sce Frère et al. ${ }^{16}$ )

Titration of the R.39 and R61 Enzymes with Cephalosporin 87-312. Samples of a solution of ecphalosporin 87-312 in either Tris- $\mathrm{NaCl- \textrm {M } _ { n } \mathrm { Cl } _ { 2 }}$ or phosphate buffer, are added stepwise at room temperature to $0.4 \mathrm{ml}$ of a solution of either R39 or RO1 enzyme in the relevant hufer. (For conentration of enzymes and cephalosporin 87-312, see legend of Fig. 6.) After anch addition, the mixture is mantained at room temperature for 5 min, after which time the absorbines of the solutions are mostred both at $386 \mathrm{~mm}$ (intact cephalosprorin) and at $482 \mathrm{~mm}$ (modified cephalo- 


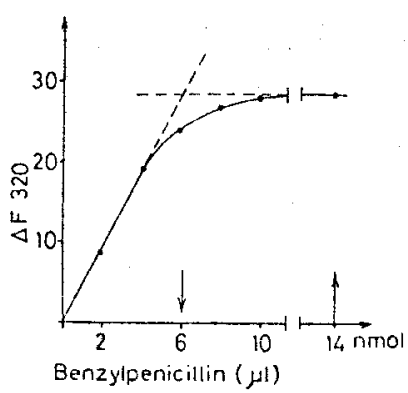

Fra. 5. Titation of the Streptomyces R61 protein with benzylyenieillin, based on thorescence quenehing at $320 \mathrm{~nm}\left(\Delta F_{: 20}\right)$. R61 cnzyme $(2 \mathrm{ml}$ of $26.5 \mu \mathrm{g} / \mathrm{ml})$ is dissolved in $10 \mathrm{mM} /$ sodium phosphate buffer, $\mathrm{pH} 7.0$, at $25^{\circ}$. Excitation is at $273 \mathrm{~nm}$ and the fuorimeter settings are: sensitivily 20, meter multiplier 0.01 . Fuoresence intensity $(F)$ is expressed in arbitrary units, the maximum emission being taken as 100. The sodium benzylenicillin solution $(0.232 \mathrm{~m} M)$ is in $10 \mathrm{mM}$ sodium phosplate hulfer, pH 7.0. Realings are taken 10 min after calch addition to allow time for muilibration. After $10 \mu$ of ponicillin solution has been added, $2.32 \mathrm{~m} M$ penicillin (5 $\mu 1)$ is adcled to ensure saturation $(\uparrow)$. The arrow $\downarrow$ indieates the titration end point. Reprinted by courtesy of the Biochemieal Society from M. Nieto, H. R. Perkins, J.-M. Frère, and J.-M. Ghuysen, Biochem. J. 135, 493 (1973).

sporin), and the DD-carboxypeptidase activity is measured in $2-\mu \mathrm{l}$ samples. With the R61 enzyme, the residual enzyme activity after each addition of $x$ moles of cephalosporin 87-312 is corrected as indicated above (see titration with benzylpenicillin). As revealed by the three procedures, the end points of the titration of both enzymes occur at a molar ratio of cephalosporin 87-312 to enzyme of 1.25:1 (Fig. 6). This high ratio might be cue to the fact that the amount of cephalosjorin 87-312 used is estimated on the basis of a $\epsilon_{386}$ value of 17,500 . An underestimation of this coefficient would result in an overestimation of the amount of antibiotic required to estimate the enzyme.

In the case of the R39 enzyme, the extinction values at 386 and 482 $\mathrm{nm}$ can be transformed into concentrations, and from these into nanomoles, of intact and modified cephalosporin 87-312 from the following eruations: ${ }^{16}$

$\epsilon_{386}=17,500$ [intact eephalosporin] +7700 [modified cephalosporin] $\epsilon_{182}=2600$ [intact cephalosporin] $+16,700$ [nodified cephalosporin]

where 17,500 and $2600=$ molar extinction coeffeients of intact cephalosporin and 7700 and $16700=$ molar extinction coefficients of cephalosporin hydrolyzed by $\beta$-lactamase, at the relevant wavelengths. 


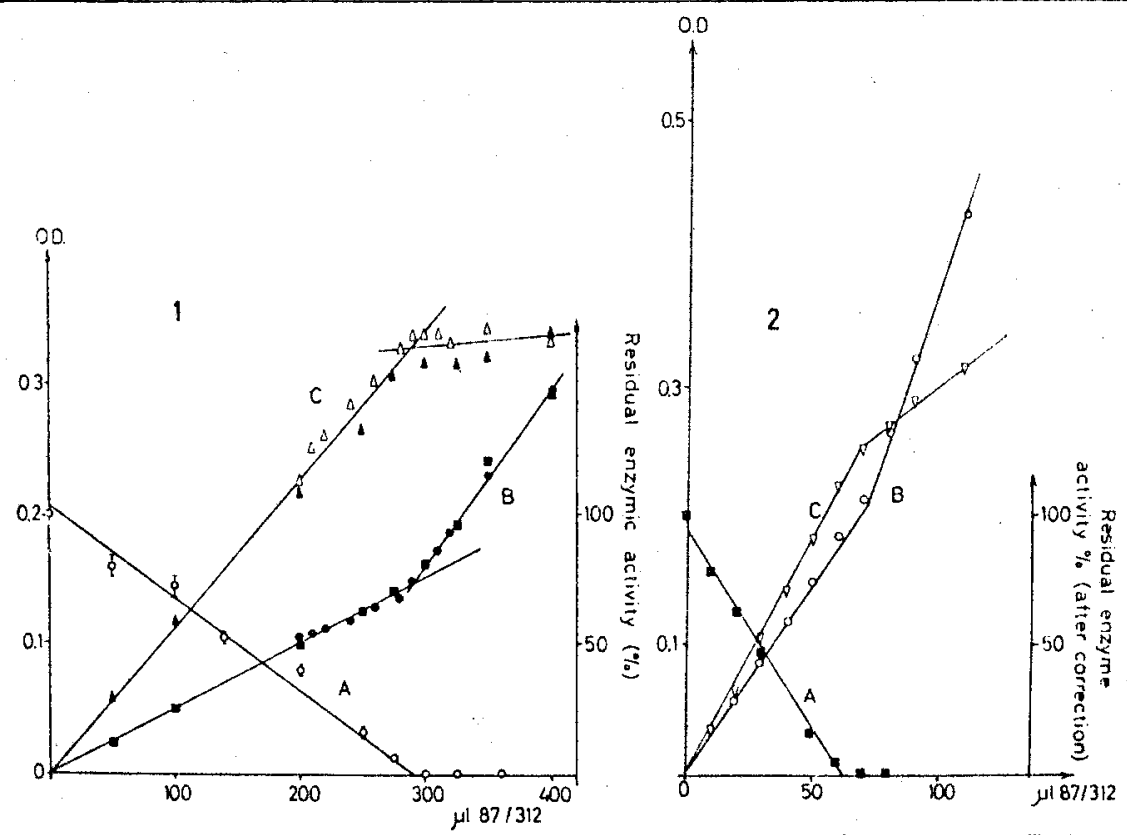

Fra. 6. Titrations of Streptomyces R39 enzyme (1) and Slreptomyees R61 enzyme (2) with cephalosporin $87-312$ based (A) on the inhibition of enzrme aldivity, (B) on the increase of the absorbance of the solution at $356 \mathrm{~mm}$, and (C) on the increase of the absorbance of the solution at $482 \mathrm{~nm}$. The R39 cuzyme (13.3 nanomoles) is titrated with a $58.8 \mathrm{M}$ cephalosporin 87-312 solution. The R61 enzyme (7.8 nanomoles) is tituted with a $0.15 \mathrm{mAI}$ (ephalosporin $87-312$ solution. After each addition of ecphalosporin 87-312, the optical deusities of the solutions atr nomalized for final rolumes of $800 \mu \mathrm{l}$ (1R39 enzyme) and $510 \mu \mathrm{l}$ (R61 enzyme). For other conditions, sec text. Reprinted by courtesy of the fideration of furopen Bioehemical Societies from J.-M. Frère, N: Loyh-Bouilla, J.-M. Ghuysen, and H. R. Perkins, Eur. J. Biochem. 50, 203 (1974).

Hydrolysis Reactions Catalyzed by the DD-Carboxypeptidases-Transpeptidases from Streptomyces R39 and R61

General Reaction

$$
\mathrm{X}-\mathrm{L}-\mathrm{R}_{3}-\mathrm{R}_{2}-\mathrm{R}_{1}(\mathrm{OII})+\mathrm{II}_{2} \mathrm{O} \rightarrow \mathrm{X}-\mathrm{I}_{-}-\mathrm{R}_{3}-\mathrm{R}_{2}(\mathrm{OH})+\mathrm{R}_{1}
$$

Standard reaction (1) is an example.

Procedure. The liberated $R_{1}$ residue can be estimated by the fluorodinitrobenzene as indicated above for alanine. Sumples containing known amounts of $R_{1}$ residue are treated similarly.

Substrate Requirements. These were studied with peptides presenting the above general sequence by measuring the amount of C-terminal $R_{1}$ 
residue released. ${ }^{11,20}$ With each enzyme, the C-terminal sequence giving the highest activity is $\mathrm{D}-\mathrm{Ala}-\mathrm{D}-\mathrm{Ala}$, but the preceding $\mathrm{L}-\mathrm{R}_{3}$ residue also has a large effect, both cnzymes exhibiting a considerable specificity for the oceurrence of a long aliphatic side chain at the $R_{3}$ position. Typieal Miehaclis-Menten kinetics are observed over a wide range of substrate concentrations.

Effects of Peptide Analogs. Peptides that are close analogs of the sulsstrate (lonor inhibit the activity of the R61 enzyme. ${ }^{21}$ Ac-D-Ala-D-Asp) behaves as a competitive inhibitor with a $K_{\mathrm{i}}$ value of $3.2 \mathrm{~m} M$ (substrate: $A c-L-L y-D-A l a-D-A l a)$. It has been suggested that the two D-Ala-D-Ala C-terminal residues of the substrates and inhibitors are mainly responsible for the initial binding whereas the side chain of the $L-R_{3}$ residue is critical in inducing catalytic activity.

None of the peptide inhibitors of the R61 enzyme have any effect on the earboxypepticlase activity of the R39 enzyme. Some of them are good substrates for this enzyme. ${ }^{21}$

\section{Concomitant Hydrolysis and Transfer Reactions Involving Distinct \\ Donor and Acceptor Peptides, Catalyzed by the DD-Carboxy- peptidases-Transpeptidases from Streptomyces R39 and R61}

General Reaction

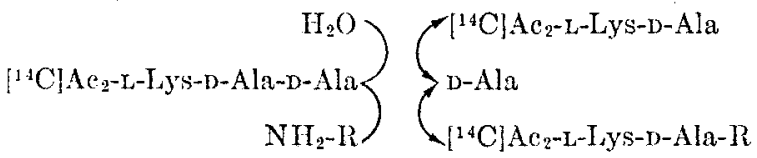

(a) = hyllolysis pathway; (b) = transfer pathway. $D$-Ala is the reaction product common to both pathways.

Donor Substrate. The tripeptide $\mathrm{Ac}_{2}-\mathrm{L}-\mathrm{LyS}-\mathrm{D}-\mathrm{Ala}-\mathrm{D}-\mathrm{Ala}$ radioactively labelect with ${ }^{1 \mathrm{C}} \mathrm{C}$ in both acetyl groups (specific activity, $10,000 \mathrm{dpm} /$ nanomole) is prepared as described by Perkins et al. ${ }^{22}$

Assay Method (with meso-Diaminopimelic Acid as Acceptor). R39 enzyme: $\left[{ }^{14} \mathrm{C}\right] \mathrm{Ac}_{2}-\mathrm{L}-\mathrm{Lys}-\mathrm{D}-\mathrm{Ala}-\mathrm{D}-\mathrm{Ala}(5 \mathrm{mM})$ and meso-diaminopimolic

"M. Leyh-Bonille, M. Nakel, J.-M. Frèce, K. Johnson, J.-M. Ghuysen, M. Nicto, and H. K. Perkins, Biochemistry 11, 1290 (1972).

${ }^{21}$ M. Nieto, H. R. Perkins, M. Leyh-Boulle, J.-M. Frère, and J.-M. Ghuysen, Biochem. J. 131, 163 (1973).

"I. R. Perkins, M. Nicto, J.-M. Frère, M. Leyh-Bouille, and J.-M. Ghuysen, Biochem.J. 131, 707 (1973). 
acid $(8 \mathrm{mM})$ are incubated at $37^{\circ}$ with 2.2 pmoles $(0.12 \mu \mathrm{g})$ of enzyme in $30 \mu$ of $0.03 \mathrm{M}$ Tris-IYCl buffer, $1 \mathrm{II} 7.5$, containing $0.1 \mathrm{H} \mathrm{NaCl}$ and $0.02 \mathrm{M} \mathrm{MgCl}$. After $30 \mathrm{~min}$, about 18 and $12.5 \%$ of the tripeptide donor

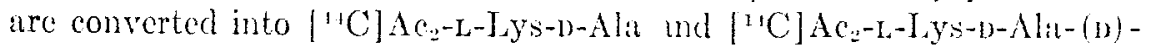
meso-diaminopimelic acid, respectively.

R61 inzyme: |"ClAce-L-Iys-1)-Ala-D-Ala $(5.5 \mathrm{~mm})$ and meso-diaminopimelic acid $(8 \mathrm{mM})$ are incubated at $37^{\circ}$ with 1.35 pmoles $(0.05$ $\mu \mathrm{g}$ ) of enzyme in $30 \mu \mathrm{l}$ of $5 \mathrm{~m} M$ sodium phosphate plI 7.0. Aiter $60 \mathrm{~min}$, about $10 \%$ of the tripeptide donor is converted into [ ${ }^{14} \mathrm{C} / \Lambda \mathrm{A}-\mathrm{L}-\mathrm{I}$ ys $\mathrm{S}-\mathrm{D}-\mathrm{Al}$ a and the same amount into $\left[{ }^{14} \mathrm{C}\right] \mathrm{Ac}-\mathrm{L}-\mathrm{Lys}-\mathrm{D}-\mathrm{Ala}-(\mathrm{D})$-meso-diaminopimelic acid.

Estinuation of $\left[{ }^{14} C\right] A c_{-2}-\mathrm{L}-L y s-\mathrm{D}-A l a-\mathrm{D}-A$ la (Residual Donor), $\left[{ }^{11} \mathrm{C}\right] A \mathrm{C}_{2}-$ L-Lys-D-Ala (IIydrolysis Product), and $\left|{ }^{1+} C\right| A c_{-2}-L y s-D-A l a-R$ (Transpeptidation Product)

\section{Reagents}

Collidine:acetic acid:water (9.1:2.65:1000, v/v/v), bufier, pH 6.4 Liquid scintillation: 2,2-p-phenylenebis (5-phenyloxazole) (P()POP), $100 \mathrm{mg} ; 2,5$-diphenyloxazole (PPO), $4 \mathrm{~g}$; toluene, 1 liter

Procedure. Samples of the reaction mixtures $(30 \mu \mathrm{l})$ contuining $10,000-$ $20,000 \mathrm{dpm}$ are diluted with $40 \mu \mathrm{l}$ of water. These are spotted as bands, $30 \mathrm{~cm}$ from the cathode on $4 \mathrm{~cm} \times 1.5 \mathrm{~m}$ strips of Whatman $3 \mathrm{MM}$ paper and subjected to electrophoresis at jill 6.4 for $4 \mathrm{hr}$ at $60 \mathrm{~V} / \mathrm{ern}$, under a Sol.T Shell. A Gilson high voltage, 10,000 V, Elertrophoretor Model DW equipped with a cooling device is used as power sourec. Residual $\left[{ }^{11} \mathrm{C}\right] \mathrm{AC}_{2}-\mathrm{L}-\mathrm{LyS}-\mathrm{D}-\mathrm{Ala}-\mathrm{D}-\mathrm{Ala}$ and the hydrolysis product $\left[{ }^{1} \mathrm{C}\right] \mathrm{Ac}-\mathrm{-}$ L-Lys-D-Ala move about 65 and $75 \mathrm{~cm}$, respectively, toward the anode. Transpeptidation products $\left[{ }^{14} \mathrm{C}\right] \mathrm{Ac}_{2}-\mathrm{L}_{-}-\mathrm{L}$ ys-D-Ala-R move differently depending upon the nature of the $R$ residue (about $55 \mathrm{~cm}$ where $R=$ mesodiaminopimelic acid). The radioactive compounds are located on the dried strips with a Packard Radiochromatogram Seanner Model 7201. Cuts of the radioactive spots $(10 \mathrm{~mm}$ section) are placed in vials, to each of which is added $0.75 \mathrm{ml}$ of the scintillation liquid. Counting is performed in a Packard Tri-Carb liquid scintillation spectrometer.

Specificity Profiles for Acceptors. The range of substrates that function as acceptors reflects the type of cross-linking that exists in the peptidoglycan of the organism which produces the exoccllular enzyme (see 
the above section: Strains). Correspondingly, glycine and many peptides with an $\mathrm{N}$-terminal glycine residue act as acceptors in transpeptidation reactions eatalyzed by the $R 61$ cnzyme (although other amino compounds also function)."- In marked contrast, suitable transpeptidation acceptors for the R39 cmzyme nust have an amino group in $\alpha$-position to the carboxyl group of a $\mathrm{D}$-amino acid (or glycine). $., 29,23$

Kinetics. The kinctics are necessarily complex. For a theoretical analysis, sec Frere." For application to the R61 enzyme (with either Gly-LAla or meso-diaminopimelic acid as acceptor) see Frère et al. ${ }^{25}$

The proportion of the enzyme activity channeled in either transpeptidation or hydrolysis depends upon the environmental conditions. ${ }^{3,23,25}$ Transpeptidation is increased and hydrolysis decreased by raising the $\mathrm{pH}$ of the reaction mixture and the concentration of acceptor within it (this latter behaves as a noneompatitive inhibitor of the hydrolysis pathway). Replacement of part of the water of the reaction mixture by a solvent of low polarity preferentially decreases the hydrolytic activity of the enzyme so that transpeptidation then largely supersedes hydrolysis. In the ease of the R39 cnzyme, transpeptidase activity is increased at high ionic strengths. ${ }^{3}$

With some peptide acceptors, transpeptidation itself is inhibited at. bigh acceptor concentrations.,23,25 For instance, when increasing concentrations of tetrapeptide L-Ala-D- $\alpha \mathrm{Gln}-(\mathrm{L})$-meso-A.pm-(L)-D-Ala are provided as acceptor to the R39 enzyme (with $0.27 \mathrm{~m} M$ Ac.-L-Lys-D-Ala$\mathrm{D}$-Ala as donor), transpeptidation rises to a maximum at an acceptor concentration of about $0.8 \mathrm{mM}$, and at higher concentrations both transpeptidation and hydrolysis reactions are progressively inhibited until eventually the tripeptide donor remains unused. In this example, this phonomon is dependent on the $\alpha$-amido group on the D-glutamic acid residue of the tetrapeptide aceptor. ${ }^{3}$

For extensive studies on the functioning of the R39 enzyme as a transpeptidase in relation to the degree of saturation of its donor site, see Ghuysen et al. ${ }^{23}$ Under conditions where the donor site of the enzyme is saturated, the rate of the total reaction (hydrolysis + transpeptidation) is the same as the rate of hydrolysis alone when no acceptor is added, i.c., the enzyme has the same turnover number for D-alanine release whether or not acceptor is present.

${ }^{23}$ J.-M. Chuysen, P. E. Reynolds, H. R. Perkins, J.-M. Frère, and R. Moreno, Biochemistry 13, 2539 (1974).

"J.-M. Frime, Biochem. J. 135, 469 (1973).

${ }^{25}$ J.-M. Frère, J.-M. Chuysen, H. R. Perkins, and M. Nicto, Biochem. J. 135, 483 (1973). 
Concomitant Hydrolysis and Transfer Reactions Catalyzed by the DD-Carboxypeptidases-Transpeptidases from Streptomyces R39 and R61 and in Which the Same Peptide Acts as Donor and Acceptor

(ieneral Reaction

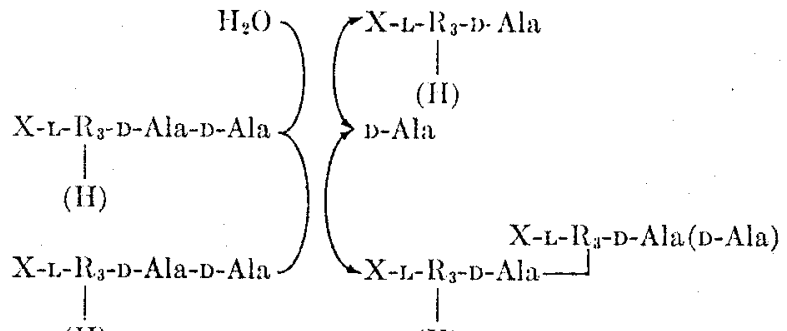

(a) hydrolysis pathway; (b) transfer pathway.

The C-terminal D-Ala-D-Ala sequence of the dimer formed can also be hydrolyzed through the carboxypeptidase activity of the enzyme.

Kinetics. Examples of such studies can be found in Ghuysen et al. ${ }^{23}$ for the 1839 enzyme substrate:

$$
\text { L-Ala-D-Glu-(L)-meso-A } 2 \text { pm-(L)-D- }\left[{ }^{14} \mathrm{C}\right] \mathrm{Ala} \text {-D- }\left[{ }^{14} \mathrm{C}\right] \mathrm{Ala}
$$

in which the amino group on the D center of meso-diaminopimelic acid functions as acceptor, and in Zeiger ef al. ${ }^{26}$ for the R61 cnzyme substrate:

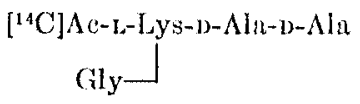

Inhibition of DD-Carboxypeptidases-Transpeptidases from

Streptomyces R39 and R61 by $\beta$-Lactam Antibiotics in the Presence of Substrates

Procedure. Ideally, the experiments are carricd out under conditions where the enzyme concentration $(10-20 \mathrm{n} M)$ is considerably lower than the concentrations of antibiotics (O.3 $\mu M$ and higher). Substrate(s), antibiotic (when present), enzyme and buffer are precooled and mixed together at $0^{\circ}$. The solutions are incubated at $37^{\circ}$ and after a given time (usually $60 \mathrm{~min}$ ) the reaction products are cstimated. For more details, sce Frère et al. ${ }^{25}$ 